\title{
The Occurrence States of Rare Earth Elements Bearing Phosphorite Ores and Rare Earth Enrichment Through the Selective Reverse Flotation
}

\author{
Wenxiang Chen ${ }^{1,2}$, Feng Zhou ${ }^{1}$, Hongquan Wang ${ }^{1}$, Sen Zhou ${ }^{1}$ and Chunjie Yan ${ }^{1, *}$ \\ 1 Engineering Research Center of Nano-Geomaterials of Ministry of Education, Faculty of Materials Science \\ and Chemistry, China University of Geosciences, Wuhan 430074, China; earst@163.com (W.C.); \\ fengzhou@cug.edu.cn (F.Z.); tang332294@126.com (H.W.); zhousen@cug.edu.cn (S.Z.) \\ 2 Guizhou Center Laboratory of Geology and Mineral Resources, Guiyang 550018, China \\ * Correspondence: chjyan@cug.edu.cn; Tel./Fax: +86-027-6788-5098
}

Received: 8 October 2019; Accepted: 4 November 2019; Published: 12 November 2019

\begin{abstract}
The reserve of rare-earth element-bearing phosphorite ores in Guizhou province in western China is huge. Increased demand for the different products manufactured from rare-earth elements has resulted in an extreme need for reasonable and comprehensive extraction of rare-earth elements. An improved understanding of rare-earth element occurrence states in single minerals of ores is important for their further processing. In this paper, rare-earth element contents were analyzed by inductively coupled plasma (ICP), and the occurrence states in single minerals were further investigated through SEM-EDS and focused ion beam-scanning electron microscope (FIB-SEM) methods. The results indicate that rare-earth element contents of apatite are far more than that of dolomite. No independent mineral of rare-earth elements exists for the studied sample. Rare-earth elements are present in the form of ions in the lattices of apatite. Based on the analysis of occurrence states and properties in single minerals, the distribution of rare-earth elements in the flotation process was investigated by reverse flotation technology. It shows that rare-earth elements are mainly concentrated in apatite concentrate. Under the optimized conditions, the $\mathrm{P}_{2} \mathrm{O}_{5}$ grade increases from $11.36 \%$ in the raw ore to $26.04 \%$ in the concentrate, and the recovery is $81.92 \%$, while the total rare-earth oxide grade increases from $0.09 \%$ to $0.21 \%$ with the recovery of $80.01 \%$, which is similar to $\mathrm{P}_{2} \mathrm{O}_{5}$ recovery. This study presents the feasibility of extracting rare-earth elements from rare-earth element-bearing phosphorite ores through the flotation of apatite.
\end{abstract}

Keywords: phosphorite ores; rare earth; apatite; occurrence states; froth flotation

\section{Introduction}

Phosphorite ores are vital nonrenewable resources and essential components in phosphorous-based chemicals and agricultural fertilizers [1]. One of the major products of phosphorite ore plants in China is a large composite ore deposit with apatite concentrate containing rare-earth elements (REEs). Recent data have estimated that total rare-earth oxide (TREO) production worldwide averages $110 \mathrm{Mt}$, with not less than $80 \%$ of production from China [2]. Several economically important phosphorite deposits occur in Guizhou Province, China. These deposits are noted for their greatly abundant REE reserves, but considerably low rare-earth oxides (REO) grade. The phosphorite ores in Guizhou hold an important position in explored apatite and rare-earth reserves of China [3].

The term REEs consists of the lanthanide series of elements, coupled with the chemically similar yttrium, and occasionally, scandium [4]. REEs and compounds are critical for a range of rapidly expanding industrial applications embracing renewable energy, agriculture, textiles, petroleum, metallurgy, catalysis, and specialty materials that rely upon their special chemical, optical, magnetic, 
and electrical properties [5]. The challenge of the REE supply due to the scarcity of mineral deposits is aggravated by the fact that the elements are never found in an equal or even predictable distribution [6]. Therefore, reasonable and comprehensive extraction of REEs is important. Many researchers have identified the organic or mineral phases in which $\mathrm{P}$ and REEs are encountered and their distribution in the geological record [7]. These studies are more about the ore characteristics, but the investigations on REE contents and the existing state in single minerals of ores were reported little. In addition, the key constraining factors of exploitation of the single minerals are occurrence states of the $\mathrm{P}$ and REEs in the phosphorite ores [8]. To aid in industrial separation of ores, it is necessary to find out the occurrence states of $\mathrm{P}_{2} \mathrm{O}_{5}$ and $\mathrm{REO}$ in independent minerals or isomorphism.

Leaching is one of the chemical methods for the beneficiation of the REEs from the phosphorite ores. Leaching is often conducted using sulfuric acid, which breaks down the crystal structure of the mineral [9] However, in this process, large amounts of toxic byproducts are produced. Various physical separation methods, such as gravity, magnetic and electrostatic separations, and most critically, froth flotation [10], are widely applied for enrichment of apatite [4]. In particular, the method of reverse flotation dolomite to enrichment apatite is the most popular one [11]. Nonetheless, flotation of REO involves several challenges owing to the discrepancies in REEs occurrence states and the considerably low-grade [12].

In this work, the mineral compositions and REE contents of the phosphorite ores were evaluated using X-ray diffraction (XRD), X-ray fluorescence (XRF), inductively coupled plasma (ICP), and scanning electron microscope-energy dispersive $\mathrm{X}$-ray spectrometer (SEM-EDS) methods. The single apatite as the main phosphoric valuable mineral and the single dolomite mineral as the main gangue mineral in phosphorite ores were separated from ores using a manual method, respectively. The existing REE states in them were measured with focused ion beam-scanning electron microscope (FIB-SEM) technology. Moreover, the rougher reverse flotation experiment was carried out to see the distribution of REE in concentrate and its corresponding tailing product. While there have been many investigations on the flotation of apatite from the phosphorite ores, there has been little reported study about the flotation of REEs from REE-bearing phosphorite ores, to the knowledge of the authors. The objectives of the present work are to provide a theoretical basis for the comprehensive development and utilization of Guizhou REE-bearing phosphorite ores and REE enrichment in this process.

\section{Experimental}

\subsection{Mineral Samples}

Phosphorite ores originating from Guizhou province in China were crushed to $90 \%$ passing $74 \mu \mathrm{m}$. Based on the XRD (D8-FOCUS, BrukerAXS, Karlsruhe, Germany, $\mathrm{Cu}-\mathrm{Ka}$ radiation) analysis, the compositions of the phosphorite ores are apatite (24-26\%), dolomite (55-57\%), quartz (15-16\%), feldspar (3-4\%). XRF (PANalytical-AxiosMAX, Almelo, The Netherlands) chemical analysis indicated that the samples contained $11.36 \% \mathrm{P}_{2} \mathrm{O}_{5}, 10.87 \% \mathrm{MgO}, 17.59 \% \mathrm{SiO}_{2}, 33.52 \% \mathrm{CaO}$, and $1.76 \% \mathrm{Fe}_{2} \mathrm{O}_{3}$ (Table 1). The REE compositions of the phosphorite ores detected by ICP (DGS-III, Shanghai, China) were given in Table 2. It is understood from this table that yttrium, with distribution of $45.86 \%$, is the predominant form of REEs in phosphorite ores. The ICP result also revealed the absence of radioactive elements (uranium and thorium) in the phosphorite ores. This considerably simplifies and cheapens the technology of obtaining the commodity REE products because the REEs extracted from phosphorite ores are also not radioactive and, hence, do not require decontamination or question about burying the radioactive wastes.

\subsection{SEM-EDS and FIB-SEM Analysis}

SEM-EDS (SU8010, Hitachi, Japan) was employed to provide morphological analysis and the composition of the apatite, dolomite, and quartz. The magnification time was fixed at $30.0 \mathrm{~K}$. Prior 
to the measurement, the samples were thoroughly ground, and then gold-coated using an ion coater under vacuum environment.

A FIB-SEM (FEI Helios 650, Hillsboro, OR, USA) equipped with an energy-dispersive X-ray spectrometer (EDS) was used to observe the microstructure of the material and collect elemental data with accompanying backscatter electron (BSE) images. Polished and grain-mounted samples were evaporatively coated with $\sim 10 \mathrm{~nm}$ of Pd. Elemental X-ray maps for different elements were acquired by EDS and TEAM Enhance V4.5-Released software.

Table 1. Chemical composition of the feed by X-ray fluorescence (XRF) analysis (wt \%).

\begin{tabular}{ccccccccc}
\hline Component & $\mathbf{P}_{2} \mathrm{O}_{5}$ & $\mathrm{MgO}$ & $\mathrm{CaO}$ & $\mathrm{SiO}_{2}$ & $\mathrm{Al}_{2} \mathrm{O}_{3}$ & $\mathrm{Na}_{2} \mathrm{O}$ & $\mathrm{K}_{\mathbf{2}} \mathrm{O}$ & $\mathrm{ZnO}$ \\
\hline Content & 11.36 & 10.87 & 33.52 & 17.59 & 1.15 & 0.08 & 0.54 & 0.01 \\
\hline Component & $\mathrm{Fe}_{2} \mathbf{O}_{3}$ & $\mathrm{MnO}$ & $\mathrm{CuO}$ & $\mathbf{P b O}$ & $\mathrm{SO}_{3}$ & $\mathrm{~F}$ & $\mathrm{Cl}$ & $\mathrm{CO}_{2}$ \\
\hline Content & 1.76 & 0.17 & 0.01 & 0.01 & 0.03 & 2.63 & 0.01 & 19.45 \\
\hline
\end{tabular}

Table 2. Rare-earth element (REE) compositions of the feed by inductively coupled plasma (ICP) analysis.

\begin{tabular}{|c|c|c|c|c|c|c|c|c|}
\hline Component & $\mathrm{La}_{2} \mathrm{O}_{3}$ & $\mathrm{CeO}_{2}$ & $\mathrm{Pr}_{2} \mathrm{O}_{3}$ & $\mathrm{Nd}_{2} \mathrm{O}_{3}$ & $\mathrm{Sm}_{2} \mathrm{O}_{3}$ & $\mathrm{Eu}_{2} \mathrm{O}_{3}$ & $\mathrm{Gd}_{2} \mathrm{O}_{3}$ & $\mathrm{~Tb}_{4} \mathrm{O}_{7}$ \\
\hline Content $/ 10^{-6}$ & 185.46 & 93.78 & 24.09 & 87.59 & 10.64 & 0.00 & 10.52 & 6.41 \\
\hline Proportion & 20.62 & 10.43 & 2.68 & 9.74 & 1.18 & 0.00 & 1.17 & 0.71 \\
\hline Component & $\mathrm{Dy}_{2} \mathrm{O}_{3}$ & $\mathrm{Er}_{2} \mathrm{O}_{3}$ & $\mathrm{Tm}_{2} \mathrm{O}_{3}$ & $\mathrm{Yb}_{2} \mathrm{O}_{3}$ & $\mathrm{Lu}_{2} \mathrm{O}_{3}$ & $\mathrm{Y}_{2} \mathrm{O}_{3}$ & $\mathrm{Ho}_{2} \mathrm{O}_{3}$ & Total \\
\hline Content $/ 10^{-6}$ & 10.36 & 6.25 & 18.03 & 4.36 & 0.57 & 412.51 & 28.94 & 899.52 \\
\hline Proportion & 1.15 & 0.70 & 2.00 & 0.48 & 0.06 & 45.86 & 3.22 & 100.00 \\
\hline
\end{tabular}

\subsection{Rougher Flotation Tests on a Laboratory Scale}

The ores were ground to $90 \%$ passing $74 \mu \mathrm{m}$, and flotation tests were carried out in a flotation machine (RK, XFD-0.5L, Wuhan, China). The pulp was conditioned at $25 \%$ solids, and the impeller speed was fixed at $2000 \mathrm{r} / \mathrm{pm}$. Analytical grade reagent $\mathrm{H}_{2} \mathrm{SO}_{4}$ was used as a $\mathrm{pH}$ regulator by adjusting the pulp pH around 6 and was conditioned for $5 \mathrm{~min}$. A desirable $\mathrm{H}_{3} \mathrm{PO}_{4}$ (depressants, $6000 \mathrm{~g} / \mathrm{t}$ ) and $\alpha$-sulfonic acid fatty acid soap (SFAS, collector, $1400 \mathrm{~g} / \mathrm{t}$ ) were added and agitated for 5 and $7 \mathrm{~min}$, respectively. The floated fraction was then gathered for $5 \mathrm{~min}$. The concentrate (unfloated fractions) and tailing (floated fractions) were dried separately and weighed to calculate the yield and the recovery. Each test was repeated thrice for which an average recovery was reported. The recovery was calculated using the following formula:

$$
\text { Recovery }(\%)=\frac{\text { Concentrate Grade } \%}{\text { Feed Grade } \%} \times \text { Concentrate yield } \% \times 100
$$

\section{Results and Discussion}

\subsection{Microstructure of the Single Minerals}

According to the XRD result, the apatite is the most abundant mineral matter, and the dolomite and quartz are the main gangue minerals in the phosphorite ores studied. Therefore, it is important to further investigate the corresponding elements' contents in single minerals. The elements' contents and existing state of the main minerals (apatite, dolomite and quartz) were analyzed by SEM-EDS.

\subsubsection{Apatite}

The main phosphoric valuable mineral was the cryptocrystalline or extremely fine crystalline apatite [13]. SEM observation shows that the apatite was spherical or ellipsoid. The results of SEM-EDS of the single apatite are presented in Figure 1. The main elements of the apatite were Ca and P. The main REEs of the apatite were $\mathrm{Y}, \mathrm{La}, \mathrm{Ce}, \mathrm{Pr}, \mathrm{Nd}$, and Ho. The concentrations of these 
REEs were 1.25-2.0 wt \%, 0.5-1.5 wt \%, 1.0-1.75 wt \%, 0.5-1.75 wt \%, 0.75-2.0 wt \%, and 1.00-2.25 wt \%, respectively. No independent mineral of REEs was found in this investigation. Therefore, apatite was the main source of REEs for the phosphorite ores. Presumably, REEs are present in the form of ions in the lattices of apatite.
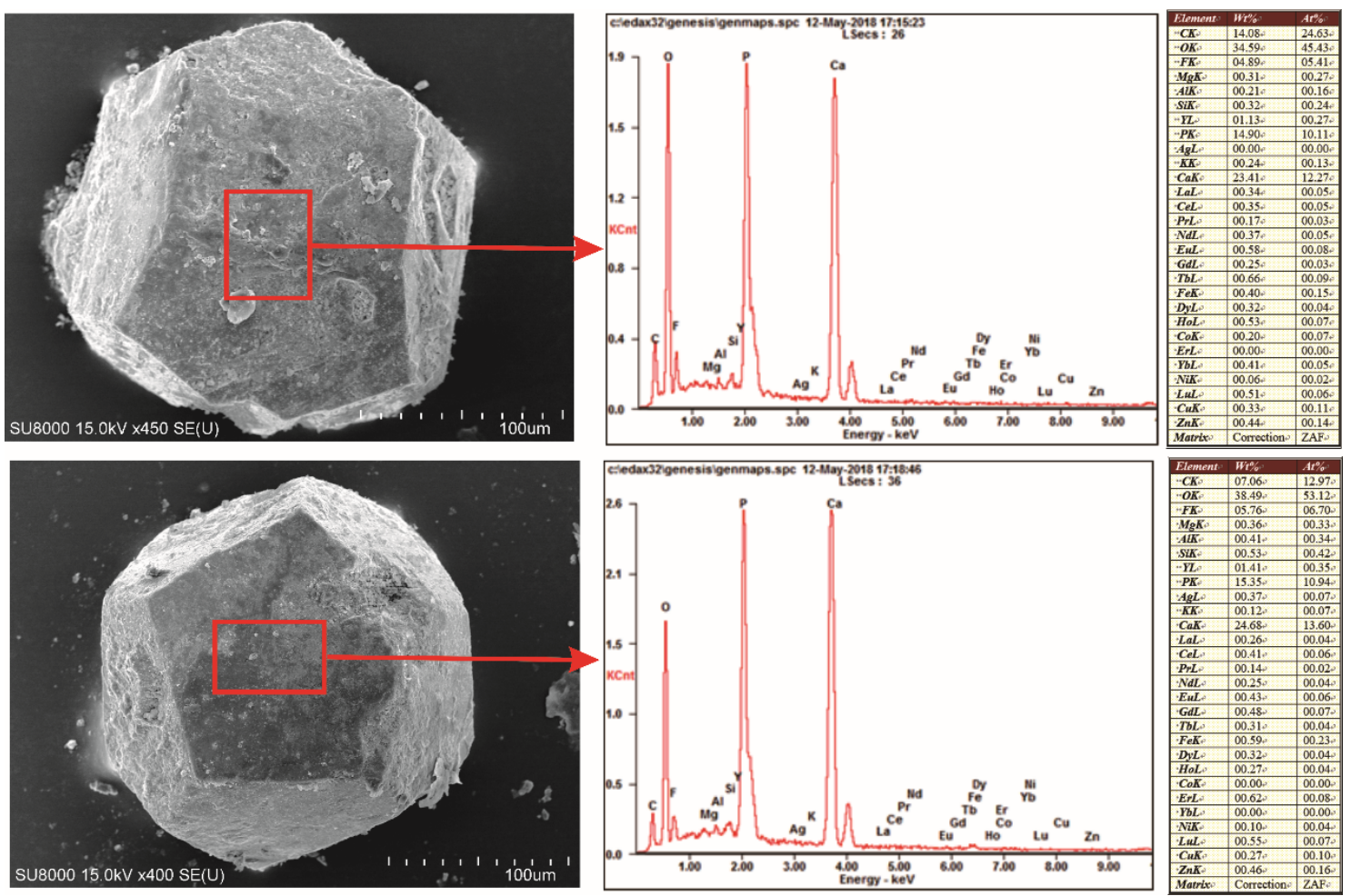

Figure 1. The microstructure and composition of apatite by using SEM-EDS analyses.

\subsubsection{Dolomite}

The dolomite had a crystal structure like that of calcite and was almost laminal or rhombohedron in shape. The dolomite grains were mainly distributed in the apatite in the form of cements. The results of SEM-EDS of the single dolomite are presented in Figure 2. The main elements of the dolomite were $\mathrm{Ca}, \mathrm{Mg}$, and $\mathrm{O}$ with an absence of REEs. After a complete survey of samples under SEM, it can be clearly seen that REEs and P contents of apatite were far more than that of dolomite.

\subsubsection{Quartz}

As for another gangue mineral, the quartz belonged to the trigonal system with a conchoidal breakage fracture. The results of SEM-EDS of the single quartz are presented in Figure 3. The main elements of the quartz were $\mathrm{Si}$ and $\mathrm{O}$ with little or no REEs.

\subsection{Hand Specimen and FIB-SEM Analysis}

Application of pretreatment in phosphorite ores was implemented in three simple steps: Desliming, dehydration, and screening. The single apatite and the paragenesis of apatite-dolomite were separated from samples using a manual method under a ZEISS-Stemi 508 electron microscope. In the hand specimen, according to the colour and hardness of these samples, typically, paragenesis was identified as combinations of apatite and dolomite (Figure 4, right). There were also some rounded grains, as single apatite (Figure 4, left) could be separated from samples using a manual method. 

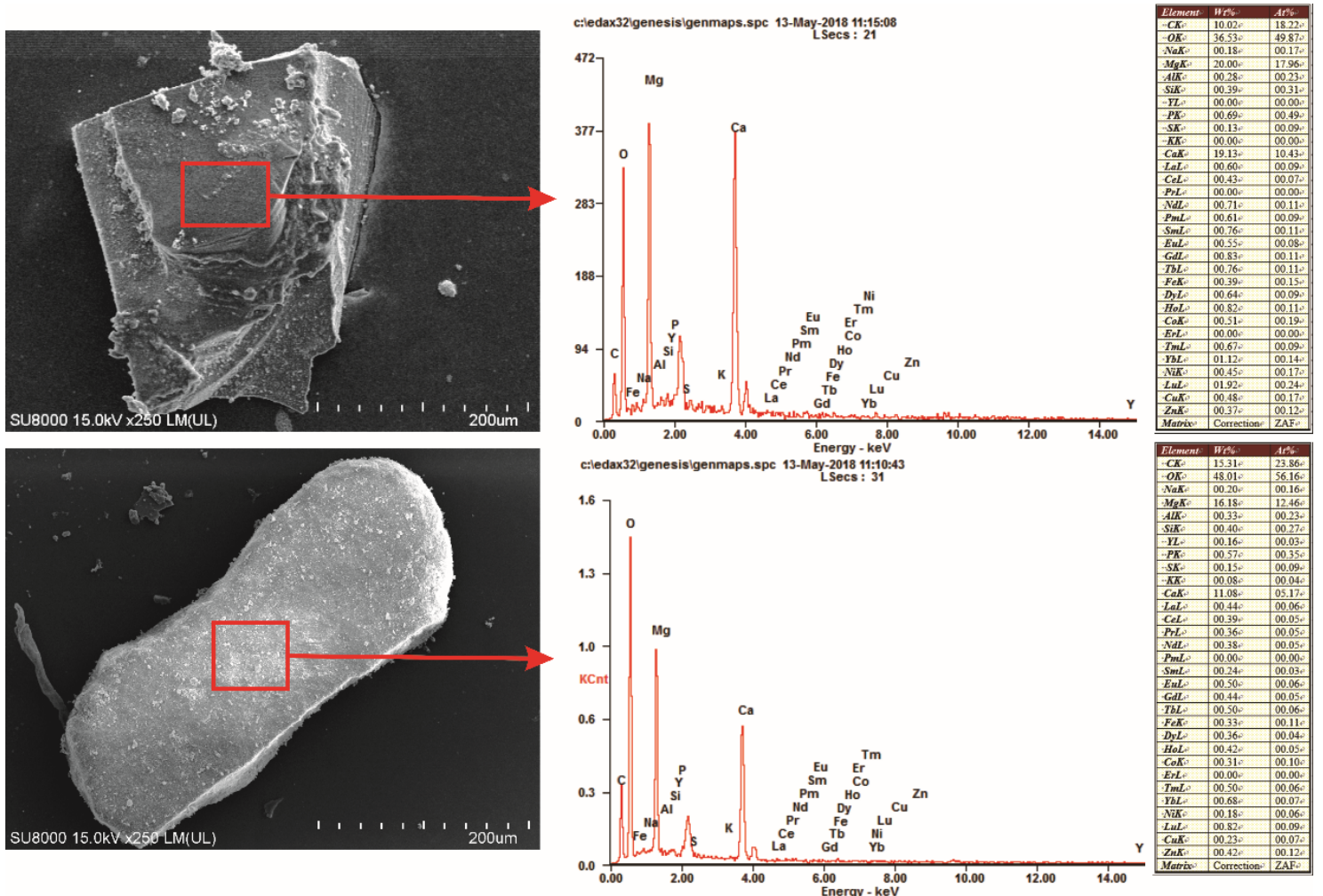

Figure 2. The microstructure and composition of dolomite using SEM-EDS analyses.
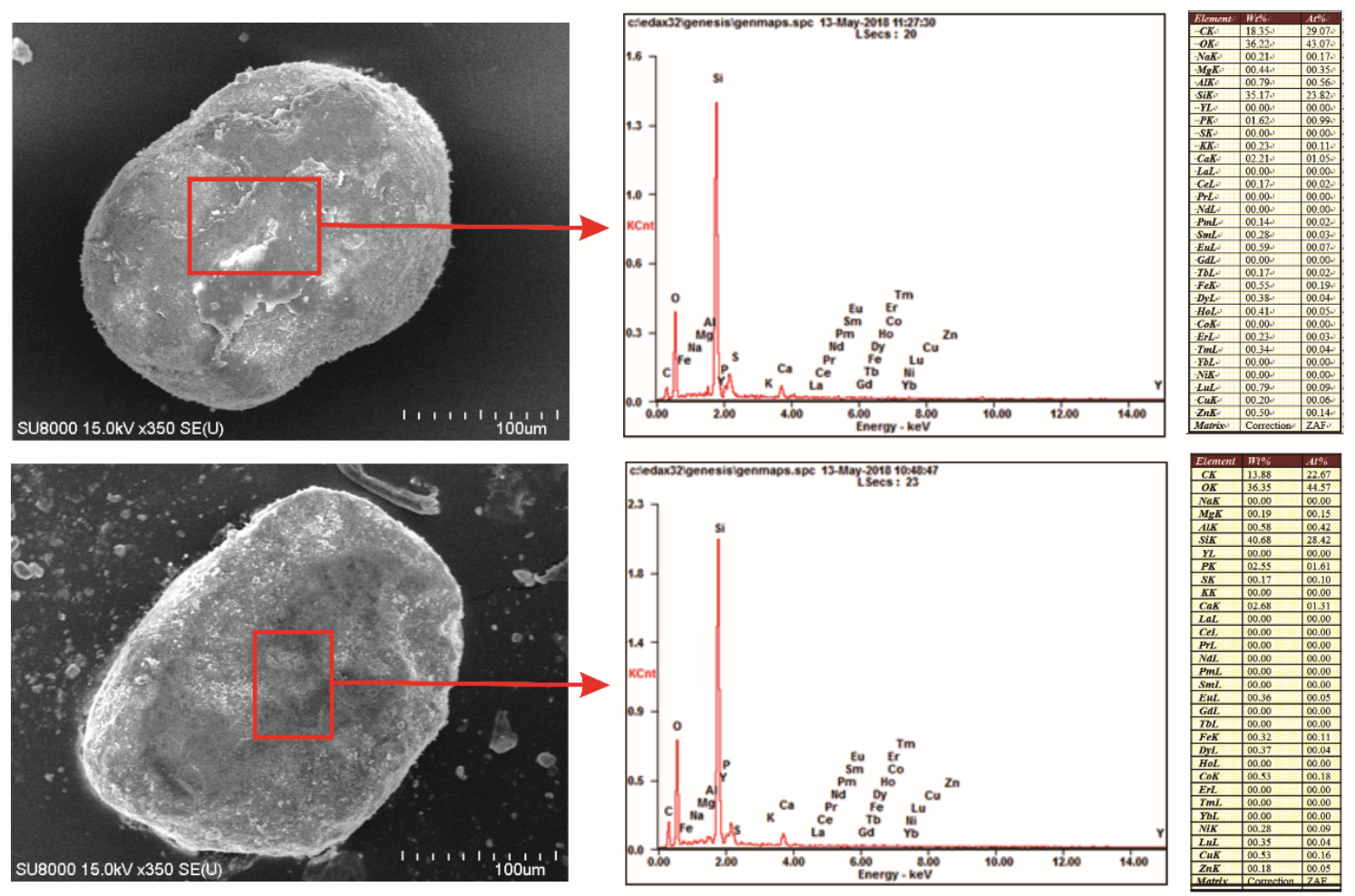

Figure 3. The microstructure and composition of quartz using SEM-EDS analyses. 


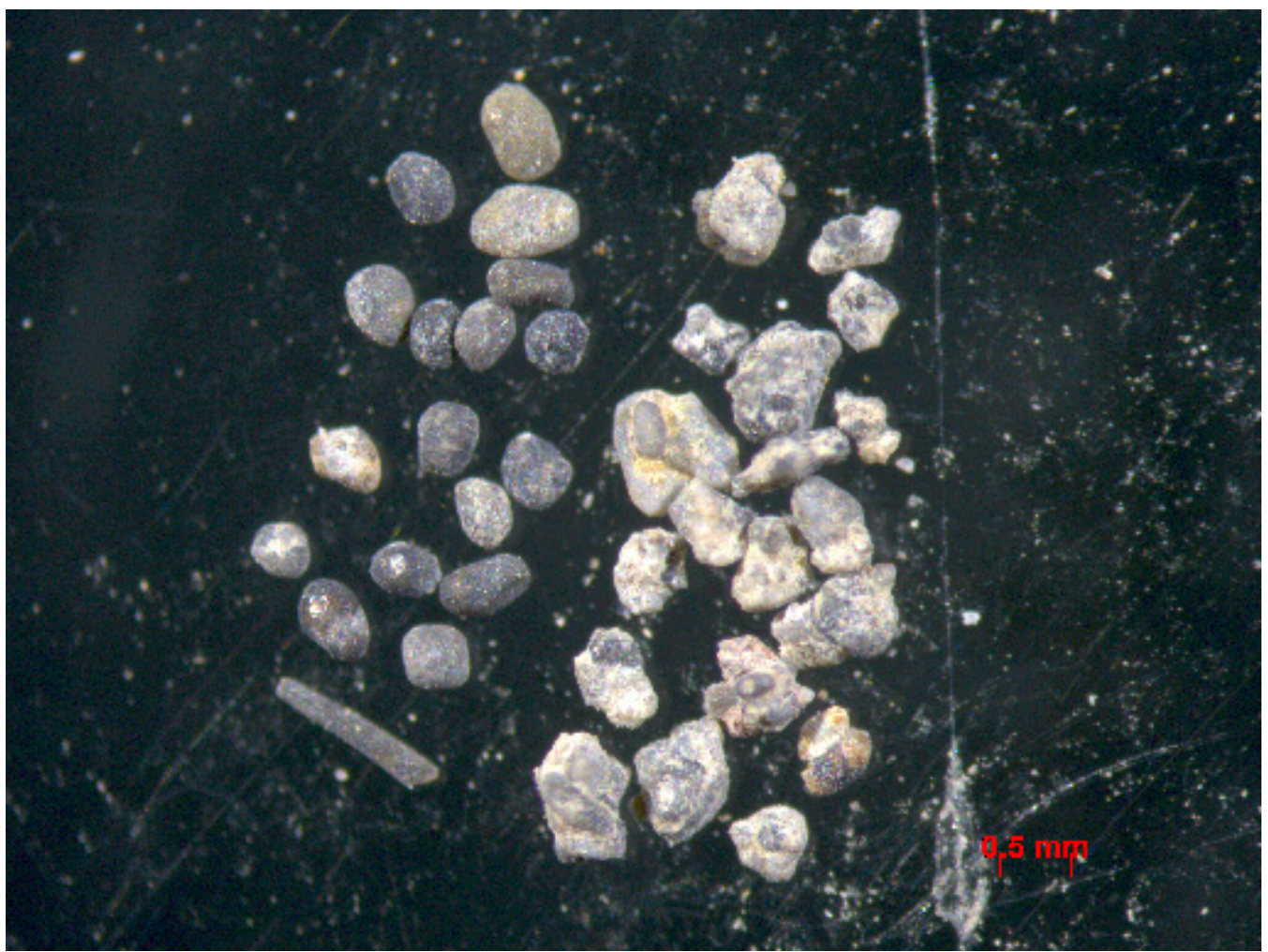

Figure 4. The single apatite (left) and the paragenesis of apatite-dolomite (right).

Based on the above SEM-EDS analysis of single minerals, the REEs were mainly present in apatite. The FIB-SEM analysis was further carried out to evaluate the main elements associated with the paragenesis mineral. Figure 5 shows the BSE images of a sample from phosphorite ores. Apatite is red and includes $\mathrm{Ca}, \mathrm{P}$, and $\mathrm{O}$. Dolomite is orange and includes $\mathrm{Ca}, \mathrm{Mg}$, and $\mathrm{O}$. The BSE imaging shows that apatite occurs as impure laminae, lenses, and round-oval nodules and is chemically homogeneous. As can also be seen in Figure 5, there is no independent mineral of REEs, such as xenotime, cerianite, and monazite in the sample studied [14]. The elemental mapping suggests that $\mathrm{Y}$ and $\mathrm{Ca}$, and $\mathrm{P}$ and $\mathrm{O}$ have the same sources, suggesting that REEs are tracked as impurities in apatite. The radii of REEs and the radius of $\mathrm{Ca}^{2+}$ are very close. REEs are supposed to be associated with apatite through replaced calcium by isomorphous [15]. Presumably, REEs are present in the form of ions in the lattices of apatite, which makes it extremely difficult to directly extract REEs from apatite. Hence, the following flotation experiment was carried out to further investigate REEs distribution in flotation products to provide valuable references for the utilization of the phosphorite ores.

\subsection{REEs Distribution of Concentrate and Tailing Products}

According to our single factor experiment results, the optimal experiment condition is a pulp density of $25 \%$, flotation $\mathrm{pH}$ of $6, \mathrm{H}_{3} \mathrm{PO}_{4}$ dosage of $6000 \mathrm{~g} / \mathrm{t}$, and collector dosage of $1400 \mathrm{~g} / \mathrm{t}$. The reverse flotation technology flowsheet is shown in Figure 6. A high-grade concentrate and its corresponding tailing product were analyzed by XRF and ICP to determine the recoveries and grades in the separated products. The experiment results of the reverse flotation of phosphorite ores under the optimal conditions are summarized in Tables 3-5. The collector SFAS exhibited stronger selectivity towards adsorption on dolomite. The apatite was rarely recovered by SAFS. The reverse flotation process of phosphorite ores realized the apatite concentrate with a $\mathrm{P}_{2} \mathrm{O}_{5}$ grade of $28.06 \mathrm{wt} \%$ and recovery of $81.92 \%$, and the grade of $\mathrm{MgO}$ in the concentrate reduced from 10.87 to $0.75 \mathrm{wt} \%$. From the investigations, it can be concluded that, from a selectivity (of apatite) standpoint, the use of collector SAFS and depressant $\mathrm{H}_{3} \mathrm{PO}_{4}$ has the effect of synergistic enhancement. The interaction between SAFS 
and $\mathrm{Mg}$ on the dolomite surface strengthened the chemisorption effect [16]. Owing to the considerable $\mathrm{Mg}$ content of dolomite and the lack of $\mathrm{Mg}$ in apatite, SFAS was selectively chemisorbed onto the dolomite surface. That is the reason why the floatability of dolomite was higher than that of apatite.
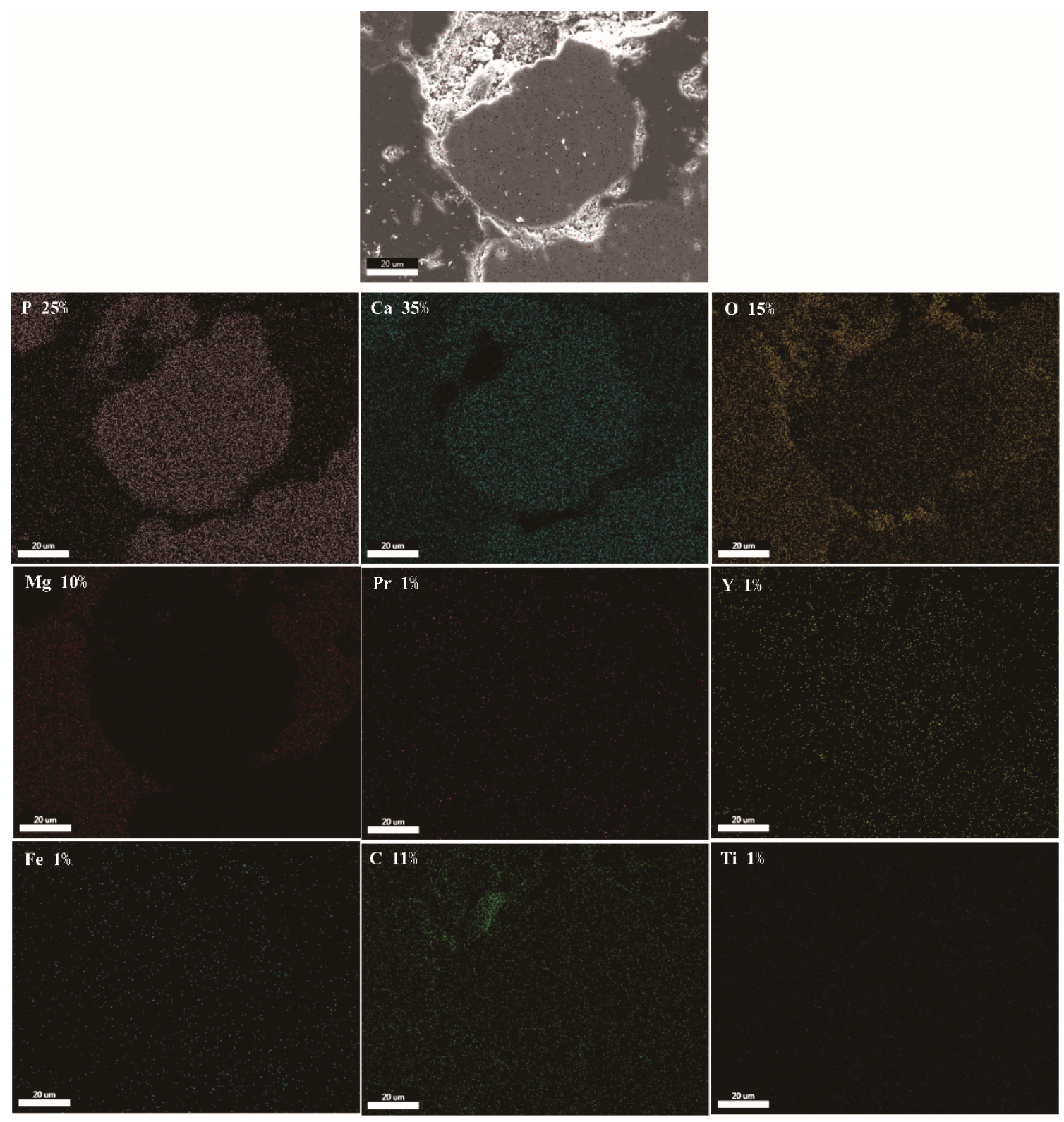

Figure 5. The backscatter electron (BSE) images of a sample from phosphorite ores using focused ion beam-scanning electron microscope (FIB-SEM) analyses.

The results of the ICP analysis (Table 4) indicated that the TREO content in the concentrate was $65.39 \%$. The TREO grade in the concentrate was $0.21 \%$, concentrating the REE by 2.3 times with respect to the feed (TREO feed grade $=0.09 \%$ ). The results confirm that $\mathrm{Y}, \mathrm{La}, \mathrm{Ce}$, and $\mathrm{Nd}$ are the major REEs in the concentrate, in the order $\mathrm{Y}>\mathrm{La}>\mathrm{Ce}>\mathrm{Nd}$. Among them, $\mathrm{Y}$ represents about $47.82 \%$ of the TREO content of the concentrate. The remaining major REE components include Pr, Gd, Sm, Tm, Tb, $\mathrm{Dy}, \mathrm{Er}, \mathrm{Yb}$, and Ho. It can also be observed from the ICP results that $80.01 \%$ of the REO content in the feed was recovered into the final flotation concentrate, and the TREO recoveries of concentrate were similar to those of the $\mathrm{P}_{2} \mathrm{O}_{5}$ recovery. 


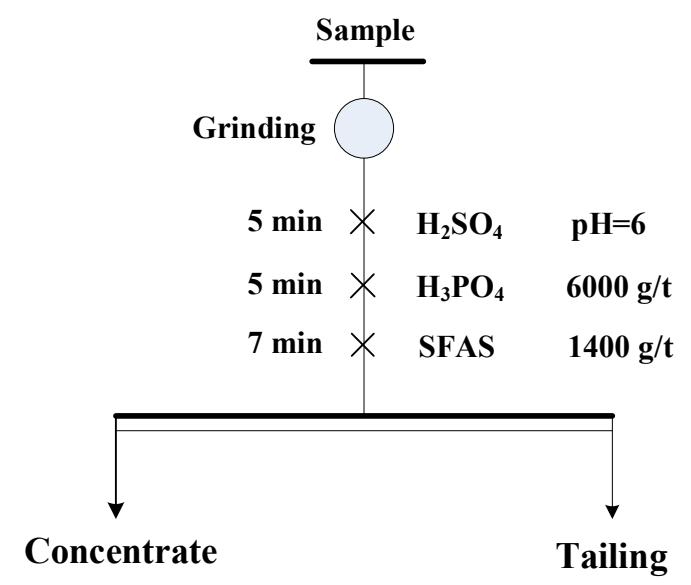

Figure 6. The rougher flotation flowsheet.

Table 3. The flotation result of $\mathrm{P}_{2} \mathrm{O}_{5}$ under the optimal flotation conditions by $\mathrm{X}$-ray fluorescence (XRF) analysis.

\begin{tabular}{ccccc}
\hline \multirow{2}{*}{ Concentrate } & \multirow{2}{*}{ Yield (\%) } & \multicolumn{2}{c}{ Grade (\%) } & \multirow{2}{*}{ Recovery (\%) } \\
\cline { 3 - 4 } & & $\mathbf{P}_{\mathbf{2}} \mathbf{O}_{5}$ & $\mathbf{M g O}$ & \\
\hline Content & 34.12 & 28.04 & 0.75 & 81.92 \\
\hline
\end{tabular}

Table 4. REE compositions of the concentrate by ICP analysis.

\begin{tabular}{|c|c|c|c|c|c|c|c|c|}
\hline Component & $\mathrm{La}_{2} \mathrm{O}_{3}$ & $\mathrm{CeO}_{2}$ & $\mathrm{Pr}_{2} \mathrm{O}_{3}$ & $\mathrm{Nd}_{2} \mathrm{O}_{3}$ & $\mathrm{Sm}_{2} \mathrm{O}_{3}$ & $\mathrm{Eu}_{2} \mathrm{O}_{3}$ & $\mathrm{Gd}_{2} \mathrm{O}_{3}$ & $\mathrm{~Tb}_{4} \mathrm{O}_{7}$ \\
\hline Content/mg/L & 417.71 & 224.00 & 54.20 & 189.08 & 23.94 & 0.00 & 23.67 & 14.42 \\
\hline Component & $\mathrm{Dy}_{2} \mathrm{O}_{3}$ & $\mathrm{Er}_{2} \mathrm{O}_{3}$ & $\mathrm{Tm}_{2} \mathrm{O}_{3}$ & $\mathrm{Yb}_{2} \mathrm{O}_{3}$ & $\mathrm{Lu}_{2} \mathrm{O}_{3}$ & $\mathrm{Y}_{2} \mathrm{O}_{3}$ & $\mathrm{Ho}_{2} \mathrm{O}_{3}$ & Total \\
\hline Content/mg/L & 23.31 & 14.06 & 39.57 & 9.81 & 1.28 & 1008.15 & 65.12 & 2108.32 \\
\hline
\end{tabular}

Table 5. The flotation result of total rare-earth oxide (TREO) under the optimal flotation conditions by ICP analysis.

\begin{tabular}{cccc}
\hline Concentrate & Yield (\%) & Grade (TREO, \%) & Recovery (\%) \\
\hline Content & 34.12 & 0.21 & 80.01 \\
\hline
\end{tabular}

The results indicate that improving $\mathrm{P}_{2} \mathrm{O}_{5}$ grade and recovery of concentrate in the flotation process would result in an improvement of TREO grades and recoveries in concentrate. The result is also in accordance with research on the microstructure of single minerals, that the REEs are mainly present in apatite and existing good correlation with phosphorus. Therefore, enrichment of REEs can be achieved through the flotation of apatite.

\section{Conclusions}

In this paper, the microstructure of single minerals and the paragenesis mineral were analyzed, and flotation studies of the phosphorite ores were carried out to further decipher the nature of the occurrence state of REEs in apatite. The following conclusions can be drawn from the above discussion:

The $\mathrm{P}_{2} \mathrm{O}_{5}$ contents and REE compositions of the phosphorite ores were analyzed by XRF and ICP methods. The apatite was the most abundant mineral matter, and the dolomite and quartz were the main gangue minerals. The ores belonged to low-grade phosphorite ores containing REEs, low $\mathrm{P}_{2} \mathrm{O}_{5}$ content, high $\mathrm{CaO}$ content, and associated low REE content.

The SEM studies show that apatite is the main source of REEs for the phosphorite ores. No independent mineral of REEs was found in this investigation. The FIB-SEM analysis indicates that 
$\mathrm{Y}$ and $\mathrm{Ca}$, and $\mathrm{P}$ and $\mathrm{O}$ have the same sources, suggesting that REEs are present in the form of ions in the lattices of apatite.

In the optimized conditions, an excellent concentrate with a $\mathrm{P}_{2} \mathrm{O}_{5}$ grade of $28.04 \%$ and recovery of $81.92 \%$ was achieved after the rougher reverse flotation. The grade of $\mathrm{MgO}$ in the concentrate reduced from 10.87 to $0.75 \%$. The TREO grade in the concentrate was $0.21 \%$, concentrating the REE by 2.3 times with respect to the feed.

ICP results showed that $80.01 \%$ of the REO content in the feed was recovered into the final flotation concentrate, and the TREO recoveries of concentrate were similar to $\mathrm{P}_{2} \mathrm{O}_{5}$ recovery. The correlation between TREO recoveries and $\mathrm{P}_{2} \mathrm{O}_{5}$ recovery is also in accordance with the research on the microstructure of single minerals, that REEs are mainly present in apatite and existing good correlation with phosphorus. Therefore, enrichment of REEs can be achieved through the flotation of apatite.

Author Contributions: Conceptualization, F.Z.; methodology, H.W.; formal analysis, W.C.; investigation, S.Z.; resources, C.Y.; data curation, C.Y.; writing-original draft preparation, W.C.; writing-review and editing, F.Z.; visualization, H.W.; supervision, S.Z.; project administration, C.Y.; funding acquisition, C.Y.

Funding: This research was funded by Guizhou Public Welfare Basic Program of Geological Exploration Foundation, the contract number: 2016-09-2, and National Key R and D Program of China, grant number 2017YFB0310805.

Conflicts of Interest: The authors declare no conflict of interest.

\section{References}

1. Gupta, D.; Chatterjee, S.; Datta, S.; Veer, V.; Walther, C. Role of phosphate fertilizers in heavy metal uptake and detoxification of toxic metals. Chemosphere 2014, 108, 134-144. [CrossRef] [PubMed]

2. Humphries, M. Rare Earth Elements: The Global Supply Chain; Congressional Research Service: Washington, DC, USA, 2013.

3. Wang, L.; Long, Z.; Huang, X.; Yu, Y.; Cui, D.; Zhang, G. Recovery of rare earths from wet-process phosphoric acid. Hydrometallurgy 2010, 101, 41-47. [CrossRef]

4. Jordens, A.; Cheng, Y.P.; Waters, K.E. A review of the beneficiation of rare earth element bearing minerals. Miner. Eng. 2013, 41, 97-114. [CrossRef]

5. Binnemans, K.; Jones, P.T.; Blanpain, B.; Van Gerven, T.; Yang, Y.; Walton, A.; Buchert, M. Recycling of rare earths: A critical review. J. Clean. Prod. 2013, 51,1-22. [CrossRef]

6. De Boer, M.; Lammertsma, K. Scarcity of rare earth elements. ChemSusChem 2013, 6, 2045-2055. [CrossRef] [PubMed]

7. Keighley, D.; McFarlane, C.; Berg, M.V. Diagenetic sequestration of rare earths and actinides in phosphatic oil shale from the lacustrine Green River Formation (Eocene), Utah, USA: An SEM and LA-ICP-MS study. J. Paleolimnol. 2018, 59, 81-102. [CrossRef]

8. Jorjani, E.; Bagherieh, A.H.; Chelgani, S.C. Rare earth elements leaching from Chadormalu apatite concentrate: Laboratory studies and regression predictions. Korean J. Chem. Eng. 2011, 28, 557-562. [CrossRef]

9. Gharabaghi, M.; Irannajad, M.; Noaparast, M. A review of the beneficiation of calcareous phosphate ores using organic acid leaching. Hydrometallurgy 2010, 103, 96-107. [CrossRef]

10. Zhou, F.; Yan, C.; Wang, H.; Zhou, S.; Liang, H. The result of surfactants on froth flotation of unburned carbon from coal fly ash. Fuel 2017, 190, 182-188. [CrossRef]

11. Matiolo, E.; Couto, H.J.B.; de Lira Teixeira, M.F.; de Almeida, R.N.; de Freitas, A.S. A Comparative Study of Different Columns Sizes for Ultrafine Apatite Flotation. Minerals 2019, 9, 391. [CrossRef]

12. Satur, J.V.; Calabia, B.P.; Hoshino, M.; Morita, S.; Seo, Y.; Kon, Y.; Takagi, T.; Watanabe, Y.; Mutele, L.; Foya, S. Flotation of rare earth minerals from silicate-hematite ore using tall oil fatty acid collector. Miner. Eng. 2016, 89, 52-62. [CrossRef]

13. McConnell, D. Apatite: Its Crystal Chemistry, Mineralogy, Utilization, and Geologic and Biologic Occurrences; Springer: Berlin, Germany, 2012.

14. Sarparandeh, M.; Hezarkhani, A. Application of unsupervised pattern recognition approaches for exploration of rare earth elements in Se-Chahun iron ore, central Iran. Geosci. Instrum. Methods Data Syst. 2017, 6, 1-16. [CrossRef] 
15. Tuo, B.; Yang, J.; Han, L.; Wang, J.; Yao, Y. Flotation experimental research of calcareous-siliceous phosphorite. Int. J. Miner. Process. 2016, 146, 10-14. [CrossRef]

16. Liu, X.; Li, C.; Luo, H.; Cheng, R.; Liu, F. Selective reverse flotation of apatite from dolomite in collophanite ore using saponified gutter oil fatty acid as a collector. Int. J. Miner. Process. 2017, 165, 20-27. [CrossRef]

(C) 2019 by the authors. Licensee MDPI, Basel, Switzerland. This article is an open access article distributed under the terms and conditions of the Creative Commons Attribution (CC BY) license (http://creativecommons.org/licenses/by/4.0/). 